\title{
PENGARUH PERBANDINGAN IKAN TEMBANG (Sardinella sp.) DAN TEPUNG TAPIOKA TERHADAP NILAI SENSORI DAN KIMIA KERUPUK IKAN
}

The Effect of Comparison of Sardinella (Sardinella sp.) and Tapioca Flour to Sensory and Chemical Value of Fish Crackers

\author{
Armin $^{1 *}$, Moh. Nuh Ibrahim ${ }^{1}$, Sri Rejeki² \\ 1Jurusan Teknologi Hasil Perikanan, Fakultas Perikanan dan IImu Kelautan Universitas Halu Oleo, Kendari, \\ Sulawesi Tenggara, Indonesia \\ 2Jurusan IImu dan Teknologi Pangan, Fakultas Pertanian Universitas Halu Oleo, Kendari, Sulawesi Tenggara, \\ Indonesia \\ *Email korespondensi: arminnippon@gmail.com (Telp: +6285299936850) \\ Diterima: 10 Januari/ Disetujui 10 Maret 2020
}

Cara sitasi: Armin, Ibrahim MN, Rejeki S. 2020. Pengaruh perbandingan ikan tembang (Sardinella sp.) dan tepung tapioka terhadap nilai sensori dan kimia kerupuk ikan. Jurnal Fish Protech. 3(1):87-94.

\section{ABSTRACT}

The aim of this study was to determine the ratio of sardinella and tapioca flour to sensory quality, proximate composition, and rising volume of fish craker fish cracker. This study used a Completely Randomized Design (CRD) consisting of (four) treatments, namely by comparison of sardinella and tapioca flour with concentrations : 40\%:60\%( $\left(P_{1}\right)$, 45\%:55\%( $\left(P_{2}\right), 50 \%: 50 \%\left(P_{3}\right)$, and 55\%:45\%(P $\left.P_{4}\right)$. Data gathered ware statistically analyzed using ANOVA (Analysis of Variance) at $0.5 \%$ significance level, if there were significant differences, the analysis was continued using DMsRT (Duncan Multiple Range Test). The results showed that the effect of ratio of sardinella and tapioca flour on the sensory (quality of color, aroma and crispness), proxsimate composition, and fish cracker rising volume had a significant effect. While other sensory attributes were not significant different. The highest proximate composition in $P_{3}$ with water content, protein, fat and ash $6,92 \%, 19,69 \%, 8,33 \%$ and $4,48 \%$ respectively. The highest value of rising volume is showed in $P_{1}$ with $91.28 \%$.

Keywords: Sardinella (Sardinella sp.), sensory, proximate, rising volume.

\section{ABSTRAK}

Penelitian ini bertujuan untuk mengetahui perbandingan dari ikan tembang dan tepung tapioka terhadap kualitas sensori, komposisi proksimat, dan daya kembang kerupuk ikan. Penelitian ini menggunakan Rancangan Acak Lengkap (RAL) yang terdiri dari 4 (empat) perlakuan yaitu dengan perbandingan ikan tembang dan tepung tapioka pada konsentrasi berturut-turut:40\%:60\% $\left(\mathrm{P}_{1}\right), 45 \%: 55 \%\left(\mathrm{P}_{2}\right), 50 \%: 50 \%\left(\mathrm{P}_{3}\right)$ dan 55\%:45\% $\left(\mathrm{P}_{4}\right)$. Data yang terkumpul secara statistik dianalisis menggunakan ANOVA (Analysis of Varians) pada taraf nyata $0,5 \%$, jika terdapat perbedaan nyata analisis dilanjutkan menggunakan DMRT (Duncam Multiple Test Range). Hasil menunjukkan bahwa pengaruh perbandingan ikan tembang dan tepung tapioka terhadap kualitas sensori (warna, aroma dan kerenyahan), komposisi proksimat dan uji fisik berpengaruh nyata. Atribut sensori rasa tidak menunjukkan perbedaan nyata. Komposisi proksimat terbaik ditunjukkan oleh perlakuan $\mathrm{P}_{3}$ yaitu kadar air 6,92\%, kadar protein 19,69\%, kadar lemak 8,33\% dan kadar abu $4,48 \%$. Komposisi volume pengembangan terbaik ditunjukkan oleh perlakuan $\mathrm{P}_{1}$ dengan nilai $91,28 \%$.

Kata kunci: Ikan Tembang (Sardinella sp.), Sensori, Proksimat, Volume Pengembangan 


\section{PENDAHULUAN}

Sulawesi Tenggara (Sultra) merupakan salah satu wilayah di Indonesia dengan potensi perairan laut yang luas arealnya mencapai $\pm 14.879 \mathrm{~km}^{2}$, dengan panjang garis pantai $1.740 \mathrm{~km}$. Wilayah laut dan garis pantai yang cukup luas menjadikan Sulawesi Tenggara sebagai salah satu wilayah dengan potensi budidaya dan perikanan laut yang sangat potensial untuk dikembangkan Asriyana et al.,(2009).

Perairan laut Sulawesi Tenggara khususnya kota kendari memiliki potensi sumberdaya ikan tembang yang sangat melimpah. Hal ini dibutkikan dalam jurnal iktiologi indonesia keaneka ragaman ikan diteluk kendari sulawesi tenggara, 9 (2): 97-112, oleh Asriyana et al., (2009), hasil tangkapan jenis ikan pelagis kecil diantaranya Sardinella fimbriata mempunyai persentase tertinggi $(35 \%)$ di Stasiun I (perairan di sekitar muara sungai, inlet) (Mandonga, Kadia, Wanggu, dan Kambu) dibanding jenis lainnya dengan kisaran panjang 9,8-4,9 cm. Di Stasiun II (perairan bagian tengah) daerah ini merupakan daerah transisi dengan kedalaman berkisar antara 5 sampai 10 meter, banyak terdapat $S$. longiceps mempunyai persentase tertinggi (64\%) dengan kisaran panjang 10-15,8 cm. Di Stasiun III (perairan dekat mulut teluk, outlet) daerah ini melingkupi sekitar mulut teluk yang lebih banyak dipengaruhi oleh masuknya air laut dari luar Teluk Kendari. Selain itu daerah ini relatif dalam dengan kedalaman sekitar 10 sampai 20 meter, banyak terdapat juvenil Plotosus canius mempunyai persentase tertinggi $(63 \%)$ dengan kisaran panjang $1,5-2,9 \mathrm{~cm}$.

Manfaat ikan tembang sangat penting karena ikan tembang mengandung beberapa komponen zat gizi yang sangat diperlukan oleh tubuh manusia seperti energi, protein, lemak, karbohidrat, abu, kalsium, fosfor, besi, vitamin $A$, vitamin $B$ dan vitamin $B 1$ yang dapat mencegah kanker, membangun sistem kekebalan tubuh dan menguatkan tulang (Supriyanto, 1987).

Ikan tembang terkenal sebagai ikan pelagis kecil yang hidup bergerombol, dikenal juga dengan kelompok ikan sardine ikan ini belum banyak dimanfaatkan oleh masyarakat sebagai sumber pangan karena cepat terjadi pembusukan sehingga biasanya diolah menjadi pindang, ikan kering dan dikalengkan/sarden. Untuk itu salah satu upaya pemanfaatan ikan tersebut untuk memiliki nilai jual yang tinggi adalah dijadikan produk olahan yang disukai dan digemari dan bisa dibawah kemanakemana dan memiliki kandungan gizi baik untuk tubuh yakni dengan cara diolah menjadi kerupuk ikan tembang yang kaya akan protein.

Kerupuk merupakan salah satu makanan khas Indonesia terutama Sulawesi Tenggara yang digemari oleh banyak kalangan karena rasanya yang renyah dan gurih. Menurut Koswara (2009), kerupuk merupakan jenis makanan kecil yang mengalami pengembangan volume membentuk produk yang porus dan mempunyai densitas rendah selama proses penggorengan.

Penambahan ikan tembang dalam kerupuk diharapkan dapat mempengaruhi karakteristik kimia kerupuk ikan yang kaya akan protein, seperti yang dijelaskan Taewee (2011), ikan merupakan sumber protein utama dalam pembuatan kerupuk, semakin besar daging ikan ditambahkan, maka kandungan protein akan semakin meningkat. Oleh karena itu, perlu dilakukan variasi peningkatan nilai gizi, salah satunya kerupuk yang dibuat dari penambahan ikan tembang.

\section{METODE PENELITIAN}

\section{Alat dan Bahan}

Alat yang digunakan pada penelitian ini ada 2 macam yaitu alat pengolahan alat kimia untuk analisis. Alat pengolahan meliputi : Alat pengolahan meliputi: baskom stainless stell, pisau, blender (Philips), panci (Aluminium Ware), kompor (Rinnai), thermometer suhu minyak, dan stopwatch (aplikasi handphone). Alat untuk analisis proksimat Alat untuk analisis proksimat meliputi: alat ekstraksi soxhlet (Pyrex), tanur (Nabertherm), gelas piala (Pyrex), gelas ukur (Phyrex), batang pengaduk (lokal), pipet tetes (lokal), pipet mikro (Socorex), corong (Pyrex), tabung reaksi (Pyrex), labu 
takar (Pyrex), erlenmeyer (Pyrex), buret (Pyrex), desikator (Duran), timbangan analitik (Matrix), cawan petri (Pyrex), penjepit cawan (lokal), gegep (lokal), cawan porselin (Pyrex), cawan aluminium (lokal), botol semprot ( lokal) dan spektofotometer UV-Vis (WTW).

Bahan yang digunakan dalam penelitian ini adalah ikan tembang (Sardinella sp.) yang di peroleh dari pelelangan kota Kendari Sulawesi Tenggara.

\section{Rancangan Penelitian}

Penelitian ini menggunakan Rancangan Acak Lengkap (RAL) yang terdiri dari dari empat perlakuan yaitu $\mathrm{P}_{1}$ (ikan tembang $40 \%$ : tepung tapioka $60 \%$ ) $\mathrm{P}_{2}$ (ikan tembang $45 \%$ : tepung tapioka $55 \%$ ), $P_{3}$ (ikan tembang 50\%: $50 \%$ tepung tapioka) dan $\mathrm{P}_{4}$ (ikan tembang $55 \%$ : tepung tapioka $45 \%$ ), masing-masing lama pengukusan 120 menit. Setiap perlakuan di ulang sebanyak 3 ulangan, sehingga diperoleh 12 unit percobaan.

\section{Pembuatan Kerupuk \\ Penyiapan Bahan Baku}

Ikan tembang dibersihkan terlebih dahulu, ikan tembang yang telah bersih kemudian difilet untuk dipisahkan dari tulang dan daging, tulang dan kepala ikan tembang dikukus selama 10 menit pada suhu $100^{\circ} \mathrm{C}$ menggunakan panci kukus (Purnanila, 2010). Tulang ikan ditiriskan dan dicuci menggunakan air mengalir untuk memisahkan daging yang melengkat pada tulang, tulang ikan yang sudah bersih dari daging kemudian di oven pada suhu $60^{\circ} \mathrm{C}$ selama 4 jam, tulang ikan yang sudah kering, dilakukan proses penepungan menggunakan blender kering sebanyak 3 kali dengan, kecepatan normal, masing-masing selama 2 menit dengan waktu istrahat 1 menit, tepung tulang ikan disimpan dalam toples untuk bahan, daging ikan tembang digiling menggunakan penggiling daging (philips), daging ikan tembang yang telah digiling kemudian di campur aduk dengan tepung tulangnya sampai merata.

\section{Pembuatan Adonan Kerupuk Ikan}

Pembuatan adonan adalah percampuran semua bahan (tepung tapioka, ikan tembang yang sesuaikan dengan perlakuan, garam 3 gram, bawang putih 6
Bahan pendukung adalah tepung tapioka, bawang putih, telur, garam, merica, air, minyak goreng. Bahan kimia untuk analisis Proksimat adalah aquades, $\mathrm{Na}_{2} \mathrm{SO}_{4}, \mathrm{CuSO}_{4}$, reagent biuret, larutan standar protein, alkohol 80\%, n-heksan, $\mathrm{NaOH}, \mathrm{HCL}, \mathrm{NaCl}$, indikator Conway dan kertas saring, kapas bebas lemak.

gram, merica $1 \mathrm{gram}$, telur $44 \mathrm{~g} / 1$ butir dan air $30 \mathrm{ml}$ ), setelah tercampur semua diadon selama 15 menit hingga merata, untuk mengetahui adonan tersebut sudah betul-betul homogen dengan cara apabila adonan tersebut dipegang dengan tangan tidak lengket berarti menunjukan sudah siap atau sudah homogen.

\section{Pencetakan}

Setelah proses pembuatan adonan selesai, adonan dicetak menggunakan daun pisang berbentuk lontongan (silinder) dengan pajang $20 \mathrm{~cm}$ dengan diameter $3 \mathrm{~cm}$.

\section{Pengukusan}

Adonan yang dicetak kemudian dikukus dalam satu panci yang sama dengan waktu selama 120 menit pada suhu $100^{\circ} \mathrm{C}$. Untuk mengetahui adonan yang telah dikukus telah matang adonan ditusuk dengan menggunakan lidi, jika adonan masih menempel pada lidi menandakan adonan belum matang dan sebaliknya jika tidak ada adonan yang menempel pada lidi menandakan adonan sudah matang.

\section{Pendinginan}

Setelah adonan masak, adonan diangkat dari dalam panci kukusan, kemudian didinginkan disuhu ruang selama $24 \mathrm{jam}$.

\section{Pengirisan}

Setelah dingin adonan di iris dengan ketebalan $2 \mathrm{~mm}$ dengan menggunakan pisau.

\section{Pengeringan}

Pengeringan yang dilakukan dalam penelitian ini adalah dengan menggunakan oven yakni pengeringan moderen dengan suhu $45^{\circ} \mathrm{C}$ selama 24 jam. 


\section{Penggorengan}

Penggorengan dilakukan dalam minyak 800 $\mathrm{ml} / 0,8 \mathrm{~kg}$ pada suhu $120^{\circ} \mathrm{C}$ dengan lama waktu penggorengan 10 detik sampai kerupuk mengembang (Alfisyahrica, 2015).

\section{Parameter uji}

Uji Sensori (SNI. 01-2346. 2006), Uji Fisik (Volume Pengembangan Zulviani, 2000). Analisis uji kimia meliputi kadar abu (AOAC, 2005), kadar air (AOAC, 2005), kadar protein (AOAC,2005), kadar lemak (AOAC, 2005).

\section{Analisis Data}

Untuk mengetahui pengaruh perlakuan terhadap parameter yang akan diamati maka akan dilakukan sidik ragam (ANOVA) dan jika terdapat pengaruh nyata pada perlakuan yang diberikan maka akan dilanjutkan dengan uji DMRT pada tingkat kepercayaan $95 \%(\alpha=0,05)$. Analisis data sensoris menggunakan software SPSS versi 16.0 (Steel and Torrie, 1995).

\section{HASIL DAN PEMBAHASAN}

Hasil rerata hasil nilai uji sensori, volume pengembangan dan uji kimia dapat dilihat pada tabel sebagai berikut :

Tabel 1. Rerata nilai uji sensori

\begin{tabular}{llccc}
\hline Parameter & \multicolumn{4}{c}{ Perlakuan } \\
\cline { 2 - 5 } & Warna \pm SD & Aroma \pm SD & Rasa \pm SD & Kerenyahan \pm SD \\
\hline P1 & $7,34^{\mathrm{c}} \pm 0.51$ & $6,80^{\mathrm{a}} \pm 0.73$ & $6,98 \pm 0.74$ & $7,75^{\mathrm{c}} \pm 0.86$ \\
P2 & $7,15^{\mathrm{b}} \pm 0.73$ & $7,22^{\mathrm{b}} \pm 0.66$ & $7,19 \pm 0.61$ & $7,30^{\mathrm{b}} \pm 0.80$ \\
P3 & $6,83^{\mathrm{a}} \pm 0.85$ & $7,40^{\mathrm{b}} \pm 0.69$ & $7,36 \pm 0.67$ & $6,86^{\mathrm{a}} \pm 0.73$ \\
P4 & $6,65^{\mathrm{a}} \pm 0.86$ & $7,45^{\mathrm{b}} \pm 0.83$ & $7,43 \pm 0.85$ & $6,62^{\mathrm{a}} \pm 0.89$ \\
\hline
\end{tabular}

Keterangan : Angka-angka yang diikuti oleh notasi huruf yang sama menunjukkan hasil yang pengaruh tidak nyata berdasarkan uji DMRT 0,05 taraf kepercayaan $95 \%$.

Tabel 2. Rerata uji volume pengembangan (uji fisik)

Perlakuan Rerata Volume Pengembangan \pm SD

$\begin{array}{ll}\mathrm{P}_{1} & 91,28^{\mathrm{b}} \pm 12,2 \\ \mathrm{P}_{2} & 66,75^{\mathrm{a}} \pm 7,87 \\ \mathrm{P}_{3} & 56,76^{\mathrm{a}} \pm 5,65 \\ \mathrm{P}_{4} & 54,26^{\mathrm{a}} \pm 3,75\end{array}$

Keterangan : Angka-angka yang diikuti oleh notasi huruf yang sama menunjukkan hasil yang pengaruh tidak nyata berdasarkan uji DMRT 0,05 taraf kepercayaan $95 \%$.

Tabel 3. Rerata uji kandungan kimia

\begin{tabular}{|c|c|c|c|c|}
\hline \multirow[t]{2}{*}{ Parameter } & \multicolumn{4}{|c|}{ Perlakuan } \\
\hline & Air \pm SD & \pm SD & Lemak \pm SD & Abu \pm SD \\
\hline P1 & $7,68^{b} \pm 0.11$ & $13,67^{a} \pm 0.22$ & $7,70^{b} \pm 0.11$ & $3,39 \mathrm{a} \pm 0.00$ \\
\hline P2 & $7,15^{a} \pm 0.21$ & $17,88^{b} \pm 0.09$ & $7,58^{a} \pm 0.22$ & $3,60^{b} \pm 0.00$ \\
\hline P3 & $6,92^{\mathrm{a}} \pm 0.02$ & $19,65^{c} \pm 0.14$ & $8,3^{c} \pm 0.34$ & $4,38^{c} \pm 0.10$ \\
\hline P4 & $6,90^{\mathrm{a}} \pm 0.00$ & $17,85^{b} \pm 0.20$ & $9,06^{d} \pm 0.29$ & $5,09 \mathrm{~d} \pm 0.12$ \\
\hline
\end{tabular}

Keterangan : Angka-angka yang diikuti oleh notasi huruf yang sama menunjukkan hasil yang pengaruh tidak nyata berdasarkan uji $\mathrm{DMRT}_{0,05}$ taraf kepercayaan $95 \%$. 


\section{Uji Sensori}

\section{Warna}

Penambahan ikan tembang pada setiap perlakuan diperoleh nilai tertinggi pada perlakuan $\mathrm{P}_{1}$ memiliki nilai rata-rata tertinggi $(7,34)$, sedangkan nilai rerata terendah terdapat pada perlakuan $P_{4}(6,65)$. Semakin banyak kosentrasi tepung tapioka yang ditambahkan, warna kerupuk ikan yang dihasilkan semakin baik disukai yaitu berwarna putih, permukan utuh dan rapih. Hal ini sesuai dengan Winarno (2002), penambahan tepung tapioka yang lebih banyak dengan perlakuan lainnya menyebabkan warna pada perlakuan berwarna lebih putih.

Penurunan nilai warna pada perlakuan $\mathrm{P}_{4}$ disebabkan oleh penambahan ikan tembang yang semakin meningkat. Bertambahnya kosentrasi ikan tembang yang ditambahkan menyebabkan warna kerupuk ikan tembang yang dihasilkan kurang halus dan dan kurang putih. Hal ini sesuai dengan pendapat Nurainy et al., (2015), semakin tinggi penambahan bahan yang non pati yang ditambahkan kedalam adonan kerupuk, maka akan menurunkan warna kerupuk yang dihasilkan.

\section{Aroma}

Penambahan ikan tembang pada setiap perlakuan diperoleh nilai tertinggi pada perlakuan $\mathrm{P}_{4}$ memiliki nilai rata-rata tertinggi $(7,45)$, sedangkan nilai rerata terendah terdapat pada perlakuan $P_{1}(6,80)$. Tingginya nilai aroma pada perlakuan $\mathrm{P}_{4}$ karena penambahan ikan tembang lebih tinggi dari perlakuan lainnya, sehingga aroma pada kerupuk yang dihasilkan lebih tercium aroma khas kerupuk ikan. Hal ini sesuai penelitian Kamari dan Candra (2017), kerupuk yang mengandung daging ikan bulan-bulan 30-50\% memberikan respon sifat sensoris hedonik dengan nilai modus 4 (suka), sedangkan kerupuk kontrol memberikan respon sifat sensoris hedonik dengan nilai modus 3 (netral). Kerupuk yang mengandung daging ikan mempunyai aroma ikan, sedangkan kerupuk kontrol tidak beraroma ikan.

Penurunan nilai aroma pada perlakuan $\mathrm{P}_{1}$ dikarena konsentrasi tepung tapioka lebih banyak, sehingga aroma ikan tembang kurang spesifik. Hal ini sesuai dengan penelitian Layla (2014), bahwa perbandingan tepung sagu dan ikan gabus formula $A$ (50:50) disukai dan $B$ (70:30) kurang disukai panelis karena tepung sagu menutupi aroma ikan gabus pada produk kerupuk ikan gabus yang dihasilkan sehingga aroma ikan gabus kurang spesifik.

\section{Rasa}

Penambahan ikan tembang pada setiap perlakuan diperoleh nilai tertinggi pada perlakuan $\mathrm{P}_{4}$ memiliki nilai rata-rata tertinggi $(7,43)$, sedangkan nilai rerata terendah terdapat pada perlkauan P1 $(6,98)$. Peningkatan nilai rasa pada perlakuan $\mathrm{P}_{4}$ dikarenakan tingginya penambahan ikan tembang pada perlakuan. Hal ini sesuai dengan pernyataan Istanti (2005), rasa kerupuk ikan sapu-sapu mengalami peningkatan seiring dengan meningkatnya kosentrasi daging ikan sapu-sapu yang ditambahkan dan memiliki rasa yang khas kerupuk ikan.

Penurunan nilai rasa kerupuk ikan pada perlakuan $\mathrm{P}_{1}$ disebabkan oleh penambahan tepung tapioka yang lebih banyak dibanding ikan tembang, sehingga rasa ikan tembang yang terdapat dalam kerupuk kurang terasa atau tidak spesifik. Hal ini sesuai dengan Sandriana (2012), terhadap penambahan tepung sagu molat sebagai bahan pengikat pada kerupuk mengemukakan bahwa penggunaan konsentrasi tepung sagu $80 \%$ dan udang $40 \%$, rasa udang ditutupi oleh tepung sagu yang digunakan.

\section{Kerenyahan}

Penambahan ikan tembang pada setiap perlakuan diperoleh nilai tertinggi pada perlakuan $\mathrm{P}_{1}$ memiliki nilai rata-rata tertinggi $(7,75)$, sedangkan nilai rerata terendah terdapat pada perlakuan $\mathrm{P}_{4}(6,62)$. Tingginya nilai sensori kerenyahan pada perlakuan $\mathrm{P}_{1}$ dikarenakan banyaknya penambahan tepung tapioka pada kerupuk, semakin banyak penambahan tepung tapioka yang ditambahkan, maka semakin renyah kerupuk yang dihasilkan. Hal ini didukung oleh penelitian Kamari dan Candra (2017), kerupuk yang dihasilkan dari substitusi daging ikan bulan-bulan sebesar 50\% dan waktu pengukusan 45 dan 60 menit memberikan respon sensoris hedonik netral (3 dari skala 1-5) untuk kerenyahan, sedangkan perlakuan lainnya mendapatkan respon suka (4 dari skala 1-5). Substitusi daging ikan bulan-bulan sebesar 30 dan 
40\% menghasilkan kerupuk ikan dengan respon sensoris mutu hedonik renyah, sedangkan substitusi sebesar 50\% menghasilkan kerupuk dengan respon agak renyah.

Penurunan nilai kerenyahan pada perlakuan $\mathrm{P}_{4}$ disebabkan penambahan ikan tembang yang tinggi pada perlakuan. Makin banyak bagian ikan yang digunakan maka akan menurunkan tingkat kerenyahan. Hal ini didukung juga dengan Zulfahmi et al., (2014), kerenyahan kerupuk ikan biasanya dipengaruhi oleh kadar daging ikan, makin banyak bagian ikan yang digunakan maka akan menurun tingkat kerenyahannya.

\section{Uji Fisik}

Nilai volume pengembangan memilki rerata tertinggi pada perlakuan $\mathrm{P}_{4}(91,28 \%)$, sedangkan nilai rerata terendah terdapat pada perlakuan $\mathrm{P}_{4}(54,26 \%)$. Tingginya nilai volume pengembangan pada perlakuan $\mathrm{P}_{1}$ dikarena banyaknya penambahan konsentrasi tepung tapioka yang ditambahkan pada perlakuan. Daya kembang kerupuk akan semakin tinggi bila presentase kandungan tepung lebih banyak dibanding dengan bahan pengisi (ikan). Hal ini sesuai dengan penelitian Kamari dan Candra (2017), makin tinggi substitusi daging ikan bulan-bulan menyebabkan daya kembang kerupuk makin berkurang daya kembang (terendah) diperoleh dari kerupuk dengan substitusi daging ikan bulan-bulan $50 \%$.

Penurunan volume pengembangan pada perlakuan $\mathrm{P}_{4}$ diduga karena penambahan ikan tembang yang lebih banyak dari pada tepung tapioka. Semakin banyak penambahan bahan pengisi (ikan), maka semakin kecil volume pengembangan kerupuk pada saat digoreng. Sama halnya dengan penurunan daya kembang akibat meningkatnya kadar protein (substitusi daging ikan bulan-bulan), data respon sensoris mutu hedonik kerupuk ikan menunjukkan bahwa semakin tinggi substitusi daging ikan bulanbulan akan menurunkan respon tingkat kerenyahan kerupuk (Kamari dan Candra, 2017).

\section{Uji Kimia \\ Kadar Air}

Nilai kadar air memilki rerata tertinggi pada perlakuan $P_{1}(7,68 \%)$, sedangkan nilai rerata terendah terdapat pada perlakuan $\mathrm{P}_{4}(6,90 \%)$. Tingginya kadar air pada perlakuan $\mathrm{P}_{1}$ dikarenakan banyaknya penambahan tepung tapioka yang ditambahkan. Kadar air cenderung menurun seiring dengan bertambahnya jumlah kosenterasi daging ikan tembang yang ditambahkan. Hal ini sesuai dengan penelitian Natalia (2019), menyatakan kadar air cenderung menurun seiring dengan bertambahnya jumlah konsentrasi daging ikan gabus yang digunakan - Kadar air pada penelitian ini sesuai dengan SNI 012713-1999 tentang kerupuk ikan, dimana kadar air maksimal $11 \%$.

Penurunan kadar air pada perlakuan $\mathrm{P}_{4}$ dikarenakan penambahan ikan tembang yang lebih banyak pada perlakuan. Kandungan air mengalami penurunan sejalan dengan penambahan protein, abu dan lemak, karena selama proses pengeringan molekul-molekul air yang terikat akan dilepaskan oleh protein, pernyataan ini dikuatkan oleh Afrila et al., (2011), selama pengeringan berlangsung terjadi pelepasan molekul air oleh protein, lemak dan abu daging sehingga konsentrasi protein, lemak dan abu daging meningkat.

\section{Kadar Protein}

Nilai kadar protein memilki rata-rata tertinggi pada perlakuan $P_{3}$ (19,65\%), sedangkan nilai rerata terendah terdapat pada perlakuan $P_{1}(13,67 \%)$. Tingginya kadar protein pada perlakuan $P_{3}$ dikarenakan banyaknya penambahan ikan tembang yang ditambahkan pada perlakuan sehingga memiliki perbedaan yang nyata antara perlakuan. Hal ini sesuai penelitian Kamari dan Candra (2017), semakin tinggi kosentrasi penambahan ikan bulan-bulan, maka semakin tinggi nilai kadar protein. Substitusi daging ikan bulan-bulan sebesar sebesar 30, 40 dan $50 \%$ dalam tepung tapioka memberikan kadar protein kerupuk mentah sebesar $1,51 \%, 6,78 \%$, dan 9,19\%. Penelitian ini nilai kadar proteinnya melebihi standar SNI 01-2713-1999 tentang kerupuk ikan dengan kadar protein minimal $6 \%$. 
Penurunan nilai rata rata kadar protein pada perlakuan $\mathrm{P}_{1}$ dikarenakan jumlah kosenterasi ikan tembang yang ditambahkan sedikit dan kosentrasi tepung tapioka yang ditambahkan banyak. Hal ini sesuai dengan penelitian Zulfahmi et al., (2014), hasil kadar karbohidrat pada perlakuan tanpa perlakuan (kontrol) diperoleh hasil yang rendah karena tidak adanya tambahan daging ikan.

\section{Kadar Lemak}

Nilai kadar lemak memiliki rata-rata tertinggi pada perlakuan $\mathrm{P}_{4}(9,06 \%)$, sedangkan nilai rerata terendah terdapat pada perlakuan $\mathrm{P}_{2}(7,58 \%)$ yang tidak jauh berbedah terhadap perlakuan $\mathrm{P}_{1}(7,70 \%)$. Tingginya nilai kadar lemak pada perlakuan $\mathrm{P}_{4}$ dikarenakan banyaknya kosentrasi penambahan ikan tembang yang ditambahkan dibandingkan tepung tapioka. Banyaknya ikan tembang yang ditambahkan pada perlakuan yang menyebabkan tingginya nilai kadar lemak. Hal ini sesuai dengan penelitian Indralaya (2016), karakteristik fisiko-kimia dan sensori kerupuk pangsit dengan kombinasi tepung ikan motan (Thynnichthys thynnoides) pada perlakuan kombinasi tepung ikan motan $12,5 \%\left(A_{5}\right)$ memiliki nilai rata-rata kadar lemak paling tinggi dibandingakan perlakuan $\left(A_{0}\right)$ tanpa kombinasi dari tepung. Kandungan lemak yang terdapat pada ikan tembang memiliki kandungan lemak sekitar $15,00 \%$ dalam 100 gram, semakin banyak kosenterasi ikan tembang yang ditambahkan, maka semakin tinggi nilai kadar lemaknya. Pada penelitian ini kadar lemak pada kerupuk dengan penambahan ikan tembang melebihi syarat standar SNI 01-2713-1999 yaitu maksimal 0,5\%.

\section{Kadar Abu}

Nilai kadar abu memiliki rerata tertinggi pada perlakuan pada $\mathrm{P}_{4}(5,09 \%)$, sedangkan nilai rerata terendah terdapat pada perlakuan $\mathrm{P}_{1}(3,39 \%)$. Tingginya kadar abu pada perlakuan $\mathrm{P}_{4}$ dikarenakan

\section{DAFTAR PUSTAKA}

Afrila, A dan Budi, S. 2011. Water Holding Capacity (WHC). Kadar Protein dan Kadar Air Dendeng Sapi pada Berbagai Kosentrasi Ekstrak Jahe (Zingiber officinale Rosecoe) dan Lama Perendaman Yang Berbeda. Jurnal banyaknya penambahan ikan tembang yang ditambahkan pada perlakuan. Semakin tinggi jumlah penambahan daging ikan tembang, maka kadar abu dalam produk akan meningkat. Hal ini sesuai dengan penelitian Huda et al., (2009), dimana konsentrasi kadar abu kerupuk ikan meningkat sejalan penambahan daging ikan. Hasil penelitian ini nilai kadar abu lebih tinggi dari Standar SNI 01-2713-1999 kerupuk ikan maksimal 1\%. Tingginya kadar abu pada penelitian ini disebabkan penambahan tepung tulang ikan tembang dalam pembuatnnya sehingga terdapat beberapa kandungan mineral yang terkandung didalamnya seperti kalsium, besi dan phospat. Ikan tembang memiliki kandungan mineral yang cukup tinggi 15,5\% dalam 100 gram ikan tembang (Supriyanto, 1987).

\section{KESIMPULAN}

Dari hasil dan pembahasan dapat disimpulkan :

1. Perbandingan ikan tembang dan tepung tapioka yang berbeda memberikan pengaruh nyata terhadap uji sensori yang diamati terhadap warna, aroma dan kerenyahan dengan nilai tertinggi 7,34 , 7,45 dan 7,75 tetapi berpengaruh tidak nyata terhadap uji sensori rasa dengan nilai tertinggi 7,43 .

2. Perbandingan ikan tembang dan tepung tapioka yang berbeda memberikan pengaruh nyata terhadap uji kimia. Yaitu kadar air, kadar protein, kadar lemak dan kadar abu dengan nilai tertinggi $7.68 \%, 19.65 \%, 9.06 \%$ dan $5.09 \%$.

3. Perbandingan ikan tembang dan tepung tapioka yang berbeda memberikan pengaruh nyata terhadap volume pengembangan pada kerupuk ikan tembang dengan perlakuan terbaik terdapat pada $\mathrm{P}_{1}$ dengan nilai $69,14 \%$.

IImu dan Teknologi Hasil Ternak. 6(2) ISSN:1978 0303.

Alfisyahrica. 2015. Variasi Bagian Telur dan Presentasenya Dengan Daging Ikan Pada Proses Pengolahan Amplang Ikan Lele Dumbo 
(Clarias Gariepinus).[Skripsi]. Repositoriy Univeristas Jamber.

Asriyana, M.F. Rahardjo S dan Sukimin, D. 2009. Keanekaragaman Ikan Di Perairan Teluk Kendari Sulawesi Tenggara. Jurnal Iktiologi Indonesia, 9(2): 97-112, 2009.

Denny, P. 2010. Kajian Perlakuan Pendahuluan Terhadap Sifat Kimiawi Tepung Ikan Selama Penyimpanan. [Skrispi]. Fakultas Pertanian Universitas Sebelas Maret. Sukarakarta. AOAC. 2005. Offivall Methods of Analysis. 18 ed. Association of Offical Analytical Chemists, Washington DC.

Huda, N, Ang L, Chung X. Y, dan Herpandi. 2010. Chemical Composition, Colour and Linea Expansion Properties of Malaysian Commercial Fish Cracker (Keropok). Asian Journal of food and Agro-Industry 3(05), 473482 ISSN 1906-3040.

Indralaya. 2016. Karakteristik Fisiko-Kimia dan Sensori Kerupuk Pangsit dengan KombinasTepung Ikan Motan (Thynnichthys thynnoides). FishtecH - Jurnal Teknologi Hasil Perikanan ISSN: 2302-6936. Vol. 5, No.2: 167-177, November 2016.

Istanti, I. 2005. Pengaruh lama penyimpanan terhadap sifat fisik dan sensori kerupuk ikan sapu- sapu (Hyposarcus pardalis) yang dikeringkan dengan menggunakan sinar matahari [skripsi]. Bogor: Fakultas Perikanan dan IImu Kelautan, Institut Pertanian Bogor.

Kamari, A dan Candra, K. P. 2017. Pengaruh Substitusi Ikan Bulan-Bulan (Megalops cyprinoides) Dan Lama Pengukusan Adonan Terhadap Kualitas Kerupuk Ikan. Jurnal Teknologi Pertanian Universitas Mulawarman 2017, 12(2):39-44.

Koswara, S. 2009. Pengolahan Aneka Kerupuk. eBook Panggan.

Layla, N. R. M, Harmain dan Yusuf, N. 2014. Formulasi Kerupuk Ikan Gabus Yang Disubstitusi Dengan Tepung Sagu. IImiah Perikanan dan Kelautan 2 (2) 81- 87.

Natalia, T, Hermanto dan Kobajashi T. Isamu. 2019. Uji Sensori, Fisik Dan Kimia Kerupuk Ikan Dengan Penambahan Konsentrasi Daging Ikan Gabus (Channa striata) Yang Berbeda. J. Fish Protech 2(2).

Nurayni, F, Ribut, S, dan Dewi wulan, S. 2015. Pengaruh Perbandingan Tepung Tapioka dan
Tepung Jamur Tiram Putih (Pleurotus Oestreatus) Terhadap Volume

Pengembangan, Kadar Protein dan

Pengembangan Organoleptik Kerupuk. Fakultas Pertanian Universitas Lampung. 20:1.

Standar Nasional Indoenesia. 1999. Syarat Mutu Kerupuk Ikan. Badan Standardisasi Nasional. Jakarta.

Standar Nasional Indonesia. 2006. SNI 01-23462006. Petunjuk Pengujian Organoleptik dan Sensori. Badan Standardisasi Nasional. Jakarta.

Steel, R. G. D. and J. H. Torrie. 1995. Principles and procedures of statistics. Alih Bahasa Sumantri, B. Prinsip dan Prosedural Statistik. Edisi 4 Penerbit P. T. Gramedia Pustaka Utama, Jakarta.

Supriyanto. 2007. Proses Penggorengan Bahan Makanan Sumber Pati: Kajian Nisbah Amilosa- Amilopektin. Disertasi. Sekolah Pascasarjana. Universitas Gajah Mada. Yogyakarta.

Taewee, T. K. 2011. Cracker "Keropok". A Review on Factoris Infuencing Expansion. International Food Research Journal. ;18(3):825-836.

Winarno, F. G. 2002. Kimia Pangan dan Gizi. Jakarta: Gramedia Pustaka Utama. Jakarta.

Zulfahmi, A.N, Fronthea. S dan Romadhon. 2014. Pemanfaatan Daging ikan Tenggiri (Scomberomorus commersoni) Dengan Konsentrasi Yang Berbeda pada Pembuatan Kerupuk Ikan. Jurnal Pengolahan dan Bioteknologi Hasil Perikanan. 3(4):133139.

Zulviani, R. 2000. Pengaruh Berbagai Tingkat Suhu Penggorengan Terhadap Pola Pengembangan Kerupuk Suhu Goreng. [Skripsi]. Instituti Pertanian Bogor. 